Terbit online pada laman web jurnal : http://e-journal.sastra-unes.com/index.php/JIPS

\begin{tabular}{|c|c|c|}
\hline & Curnal Ilmiah & Pendidikan Scholastic) \\
\hline $\begin{array}{c}\text { Fakultas Sastra } \\
\text { Universitas Ekasakti }\end{array}$ & $\begin{array}{c}\text { Vol. } 5 \text { No. } 3 \\
\text { ISSN : } 2579-5449 \\
\text { (media cetak) }\end{array}$ & $\begin{array}{c}\text { E-ISSN : } \\
2597-6540 \\
\text { (media online) }\end{array}$ \\
\hline
\end{tabular}

\title{
KINERJA APARATUR SIPIL NEGARA (ASN) DI KANTOR FAKULTAS ILMU SOSIAL UNIVERSITAS NEGERI PADANG
}

\author{
Reflinda \\ STIA Adabiah Padang
}

\begin{abstract}
Penulisan penelitian ini dilatar belakangi oleh sangat pentingnya Kinerja Aparatur Sipil Negara (ASN) di Kantor Fakultas Ilmu Sosial Universitas Negeri Padang. Dengan disiplin yang tinggi serta mengikuti arahan pimpinan juga sangat menentukan kinerja serta hasil yang diharapkan dapat sesuai dengan batas waktu yang telah ditentukan sebelumnya. Tujuan dari penelitian ini adalah untuk mengetahui Kinerja Aparatur Sipil Negara (ASN) di Kantor Fakultas Ilmu Sosial Universitas Negeri Padang, untuk mengetahui kendala-kendala dalam Kinerja Aparatur Sipil Negara (ASN) di Kantor Fakultas Ilmu Sosial Universitas Negeri Padang, serta mengetahui cara-cara mengatasinya. Dalam penelitian ini peneliti menggunakan metode penelitian kualitatif dengan pendekatan deskriptif yaitu metode yang digunakan untuk menggmbarkan apa adanya sesuai fakta di lapangan. Adapun teknik pengumpulan data dalam penelitian ini adalah menggunakan teknik dokumentasi, observasi, dan wawancara.

Selanjutnya sesuai dengan masalah dan tujuan penelitian penulis, maka yang menjadi sumber data adalah Wakil Dekan II, Kabag TU, Kasubag Akademik/ Kemahasiswaan, Pegawai, Dosen, dan Mahasiswa sebagai penguat data wawancara. Dalam pengumpulan data penulis menggunakan Teknik Observasi dan Wawancara. Berdasarkan hasil penelitian didapatkan bahwa Kinerja Aparatur Sipil Negara (ASN) di Kantor Fakultas Ilmu Sosial Universitas Negeri Padang dapat lebih dtingkatkan lagi dengan kedisiplinan, arahan atasan yang jelas, serta penempatan pegawai yang sesuai dengan kemampuan agar pekerjaan dapat diselesaikan dalam batas waktu yang telah ditentukan. Bagian kemahasiswaan sebaiknya menyediakan sarana dan prasarana labor komputer untuk mahasiswa yang terkena dampak covid 19 sehingga pembelajaran jarak jauh tetap terlaksana dengan baik pada saat pandemi covid 19 ini.
\end{abstract}

Keywords: Kinerja Aparatur Sipil Negara (ASN), Kinerja Pegawai

(C) 2021Jurnal JIPS

\section{INTRODUCTION}

Penilaian kinerja merupakan tugas penting bagi organisasi publik khususnya di Fakultas Ilmu Sosial Universitas Negeri Padang untuk mengetahui level kinerja pegawai yang dimilikinya. Fakultas Ilmu Sosial merupakan salah satu Fakultas di Universitas Negeri Padang merupakan lembaga pemerintah yang bertugas menyelenggarakan urusan pemerintahan yang bergerak di bidang pendidikan tinggi. Sebagai lembaga pemerintah adalah melayani masyarakat dibidang pendidikan, sedangkan ASN adalah sebagai pelaksananya.

Rendahnya kinerja akan membangun citra buruk pada Fakultas Ilmu Sosial Universitas

Jurnal JIPS (Jurnal Ilmiah Pendidikan Scholastic) Vol. 5 No. 3 (2021) ISSN : 2579-5449

This work is licensed under a Creative Commons Attribution-NonCommercial 4.0 International License. 
Negeri, dimana masyarakat yang merasa tidak puas akan menceritakan kepada rekan- rekannya. Begitu pula sebaliknya, semakin tinggi kinerja yang diberikan akan menjadi nilai plus bagi Fakultas Ilmu Sosial Universitas Negeri, dalam hal ini akan merasa puas terhadap pelayanan yang diberikan oleh Fakultas Ilmu Sosial Universitas Negeri Padang.

Sebagai contoh dalam pengurusan bahan naik pangkat dosen maupun pegawai ASN membutuhkan kecermatan dan ketelitian yang tinggi dalam hal pemberkasan yang sesuai aturan maupun melanjutkan bahan tersebut hingga sampai ke sidang komisi, sehingga dosen maupun pegawai ASN yang mengurus bahan naik pangkat dapat mengetahui sampai dimana keberadaan bahan naik pangkat tersebut, apakah bahan tersebut lengkap atau memang perlu ditambahkan lagi bahan tersebut. Dan pegawai yang mengurus bahan naik pangkat tersebut dapat bertanggungjawab dan menyelesaikan pekerjaannya sesuai dengan waktu yang telah ditentukan.

Belum maksimalnya kinerja Aparatur Sipil Negara (ASN) juga disebabkan salah satunya adalah datang terlambat atau pulang lebih cepat dari waktu yang telah ditentukan, hal ini akan menyebabkan kurang efektif dan kurang efisien dalam pemakaian waktu untuk menyelesaikan suatu pekerjaan rutinitas dan kegiatan kampus lainnya. Kurangnya disiplin waktu kerja ini sangat diperlukan perhatian dari pimpinan sebagai atasan langsung untuk dapat mengkoordinir bawahan, surat teguran juga dapat dilayangkan jika memang ada ASN yang tidak mematuhi aturan atau terus menerus melanggar aturan yang telah dibuat. Ketidakdisiplinan waktu juga akan memberikan pengaruh buruk bagi ASN lainnya sehingga semakin banyak yang datang terlambat maupun pulang lebih cepat.

Kemudian berdasarkan dari hasil observasi awal, terindikasi beberapa masalah kinerja aparatur sipil negara yang dilanggar oleh para pegawai seperti kurang disiplinnya ASN dalam jam masuk dan pulang kerja, adanya ASN yang ditempatkan yang tidak sesuai dengan latar belakang pendidikannya sehingga merasa tidak nyaman dalam bekerja, kurangnya perhatian kepada pegawai dalam masalah perkembangan karirnya. Tidak berkembangnya karir dalam suatu pekerjaan akan menyebabkan kejenuhan tersendiri.

Pada saat pandemi covid 19 ini sangat mempengaruhi mahasiswa yang melakukan pembelajaran jarak jauh, banyaknya mahasiswa yang tidak memiliki komputer, laptop, maupun printer akan menjadi hambatan dalam pembelajaran jarak jauh yang telah diterapkan oleh pihak kampus. Ketiadaan komputer, laptop, dan printer ini disebabkan oleh ketidakmampuan orangtua mahasiswa, karena faktor ekonomi para orangtua kesulitan dalam mencari pekerjaan bahkan ada yang berhenti bekerja karena dampak pandemi covid 19 sekarang ini. Pihak kampus pun tidak menyediakan sarana dan prasarana berupa labor komputer untuk mahasiswa yang berdomisili di Padang yang terdampak pandemi covid 19 ini, alangkah sebaiknya pihak kampus menyediakan labor komputer sehingga mahasiswa bisa tetap datang ke kampus belajar jarak jauh sambil menerapkan protokol kesehatan yang telah ditetapkan.

Berdasarkan permasalahan diatas terlihat belum maksimalnya kinerja aparatur sipil negara dalam melaksanakan tugas yang diberikan kepada individu masing-masing serta kekurangan sarana dan prasarana terutama untuk mahasiswa yang terkena dampak pandemi covid 19 seperti labor komputer, sehingga peneliti tertarik untuk membuat skripsi dengan judul Kinerja Aparatur Sipil Negara (ASN) di Kantor Fakultas Ilmu Sosial Universitas Negeri Padang.

Berdasarkan permasalah di atas maka peneliti merumuskan masalahnya sebagai berikut:

1. Bagaimana Kinerja Aparatur Sipil Negara (ASN) di Kantor Fakultas Ilmu Sosial Universitas Negeri Padang?

2. Apa saja kendala-kendala yang ditemui dalam Kinerja Aparatur Sipil Negara (ASN) di Kantor Fakultas Ilmu Sosial Universitas Negeri Padang?

3. Bagaimana cara mengatasi kendala yang ditemui dalam Kinerja Aparatur Sipil Negara (ASN) di Kantor Fakultas Ilmu Sosial Universitas Negeri Padang?

Berdasarkan rumusan masalah diatas maka tujuan penelitiannya adalah sebagai berikut:

1. Untuk mengetahui Kinerja Aparatur Sipil Negara (ASN) di Kantor Fakultas Ilmu Sosial Universitas Negeri Padang.

Jurnal JIPS (Jurnal Ilmiah Pendidikan Scholastic) Vol. 5 No. 3 (2021) ISSN : 2579-5449

This work is licensed under a Creative Commons Attribution-NonCommercial 4.0 International License. 
2. Untuk mengetahui kendala-kendala yang ditemui dalam Kinerja Aparatur Sipil Negara (ASN) di Kantor Fakultas Ilmu Sosial Universitas Negeri Padang.

\section{RESEARCH METHODS}

Metode penelitian yang peneliti pakai adalah deskriptif kualitatif, jenis ini berupaya menggambarkan kejadian atau fenomena sesuai dengan apa yang terjadi di lapangan, dimana data yang dihasilkan berupa kata-kata tertulis dari orang-orang dan perilaku yang dapat diamati (Bogdan dan Taylor dalam Moeleong, 2007: 4). Metode penelitian kualitatif ini dapat digunakan untuk mendapatkan data yang mendalam, suatu data yang mengandung makna. Makna adalah data yang sebenarnya, data yang merupakan suatu nilai dibalik data yang nampak (Sugiyono, 2007: 3). Tipe penelitian kualitatif adalah riset yang bersifat deskriptif, studi deskriptif yaitu mengumpulkan data sebanyak-banyaknya mengenai faktor yang menjadi fokus peneliti, hal ini sangat relevan dengan judul penelitian yang berdasarkan fenomena yang terjadi di lapangan yang tidak mengumpulkan data saja tetapi juga menganalisa data yang telah diperoleh tersebut.

Subjek penelitian atau responden adalah orang yang diminta untuk memberikan keterangan tentang suatu fakta atau pendapat. Sebagaimana telah dijelaskan oleh Arikunto (2006: 145) subjek penelitian adalah subjek yang dituju untuk diteliti oleh peneliti, jadi subjek penelitian itu merupakan sumber informasi yang digali untuk mengungkap fakta-fakta yang ada di lapangan. Penentuan subjek penelitian atau responden dalam penelitian ini dilakukan dengan cara purposive sampling. Peneliti menentukan subjek penelitian berdasarkan permasalahan yang diteliti yaitu tentang Kinerja Aparatur Sipil Negara (ASN) di Kantor Fakultas Ilmu Sosial Universitas Negeri Padang.

Informan adalah orang yang memberikan informasi tentang situasi dan latar belakang penelitian menurut Moleong (2010: 132). Salah satu teknik pengambilan informan yang dilakukan peneliti adalah menggunakan teknik purposive sampling menurut Sugiyono (2013: 218) yaitu pengambilan sampel sumber data dengan pertimbangan tertentu. Teknik ini dipilih karena informan yang dipilih hanyalah pihak-
3. Untuk mendeskripsikan cara mengatasi kendala-kendala yang ditemui dalam Kinerja Aparatur Sipil Negara (ASN) di Kantor Fakultas Ilmu Sosial Universitas Negeri Padang.

pihak yang terkait dengan tema dan judul yang peneliti angkat. Adapun informan yang dimaksud adalah:

Tabel 3.1: Informan Penelitian

\begin{tabular}{|c|c|c|}
\hline No & Informan & Jumlah \\
\hline $\begin{array}{l}1 . \\
2 . \\
3 . \\
4 . \\
5 . \\
6 .\end{array}$ & $\begin{array}{l}\text { Dekan dan Wakil Dekan II } \\
\text { Kabag TU } \\
\text { Kasubag akademik/ kemahasiswaan } \\
\text { Pegawai } \\
\text { Dosen } \\
\text { Mahasiswa }\end{array}$ & $\begin{array}{l}2 \text { orang } \\
1 \text { orang } \\
3 \text { orang } \\
10 \text { orang } \\
11 \text { orang } \\
5 \text { orang }\end{array}$ \\
\hline & Jumlah & 32 orang \\
\hline
\end{tabular}

Sumber: Diolah sendiri

Dalam teknik Pengumpulan Data, Data adalah catatan atas kumpulan fakta. Data merupakan bukti yang ditemukan dari hasil penelitian yang dapat dijadikan dasar kajian atau pendapat. Dalam keilmuan (ilmiah), fakta dikumpulkan untuk menjadi data. Dari data tersebut kemudian diolah sehingga dapat diutarakan dengan jelas dan tepat, sehingga dapat dimengerti oleh orang lain yang tidak langsung mengalaminya sendiri, hal ini dinamakan deskripsi.

\section{a. Data Primer}

Data primer adalah data yang diperoleh langsung oleh peneliti dari sumbernya. Sumber data utama ini dicatat melalui catatan tertulis yang dilakukan melalui wawancara terhadap pihak- pihak yang terkait dengan masalah yang diteliti, baik informan maupun responden.

\section{b. Data Sekunder}

Data sekunder merupakan data yang tidak diperoleh langsung dari obyeknya, tetapi melalui sumber lain. Dalam hal ini data sekunder mencakup dokumen- dokumen resmi berisi informasi- informasi penting, buku- buku, hasil penelitian yang berwujud laporan dan sebagainya.

Teknik pengumpulan data yang digunakan menurut Sugiyono (2010: 43) adalah sumber data yang langsung memberikan data 
kepada pengumpul data adapun data yang digunakan sebagai berikut:
a. Observasi
Menurut Nasution (1988) dalam

Sugiyono (1016: 226) menyatakan bahwa, observasi adalah dasar semua ilmu pengetahuan. Menurut Marshall (1995: 67) dalam Sugiyono (2016: 226) menyatakan bahwa "through observation, the researcher learn about behavior and the meaning attached to those behavior" melalui observasi peneliti belajar tentang perilaku dan makna perilaku tersebut. Selanjutnya menurut Spradley, Susan Stainback (1988) dalam Sugiyono (2016: 227) membagi observasi berpartisipasi menjadi empat yaitu passive partisicipation, moderate participation, active participation, dan complete participation. Objek penelitian dalam penelitian kualitatif yang diobservasikan menurut Spradley dinamakan situasi sosial, yang terdiri dari tiga komponen yaitu place (tempat), actor (pelaku), dan activities( aktivitas).

\section{b. Wawancara}

Menurut Esterberg (2002) dalam sugiyono (2016: 231), dalam mendefinisikan interview sebagai berikut "a meeting of two persons to exchange information and idea through question and responden, resulting in communication and joint contruction of meating about a particular topic". Wawancara adalah merupakan pertemuan dua orang untuk bertukar informasi dan ide melalui tanya jawab, sehingga dapat dikontruksikan dalam suatu topik tertentu.

\section{c. Dokumentasi}

Menurut Sugiyono (2016: 240) dokumen merupakan catatan peristiwa yang sudah berlalu. Dokumen bisa berbentuk tulisan, gambar, atau karya-karya menumental dari seseorang. Data sekunder adalah yang dikumpulkan dari tangan ke dua atau sumber lain yang telah tersedia sebelum penelitian dilakukan (Uber Silalahi, 2010: 291) melalui pustaka seperti buku, artikel, makalah, surat kabar petunjuk pelaksana, dan lain-lain yang memiliki relevansi dengan penelitian.

Sedangkan dalam teknik pengolahan dan analisis data, analisis data dalam penelitian ini digunakan untuk mengumpulkan data- data bersifat penelitian kualitatif untuk menemukan yang diinginkan oleh peneliti. Pengolahan data yang ada selanjutnya diinterpretasikan dalam bentuk konsep yang dapat mendukung objek pembahasan.

Langkah- langkah yang digunakan dalam menganalisis data pada penelitian dapat dipaparkan dibawah ini :

\section{Reduksi Data}

Reduksi data adalah bentuk analisis yang menajamkan, menggolongkan, mengarahkan membuang yang tidak diperlukan, dan mengorganiasikan data dengan cara sedemikian rupa sehingga kesimpulan akhir dapat diambil. Peneliti mengolah data dengan bertolak pada teori- teori untuk mendapatkan kejelasan pada masalah, baik data yang terdapat dilapangan maupun yang terdapat pada kepustakaan. Data dikumpulkan, dipilih secara selektif dengan cara disesuaikan pada permasalahan yang diangkat dalam penelitian. Kemudian dilakukan pengolahan dengan meneliti ulangdata yang didapat, apakah data tersebut sudah cukup dan dapat segerah dipersiapkan untuk proses selanjutnya.

\section{Penyajian Data}

Penyajian data yang diperoleh dari lapangan terkait dengan seluruh permasalahan penelitian dipilih antara yang dibutuhkan dan yang tidak dibutuhkan, lalu dikelompokkan kemudian diberi batasan masalah. Dalam penyajian data ini, peneliti menguraikan setiap permasalahan dalam pembahasan penelitian dengan cara pemaparan secara umum kemudian menjelaskan dalam pembahasan yang lebih spesifik.

\section{Penarikan Kesimpulan \\ Upaya penarikan kesimpulan atau} verifikasi dilakukan peneliti secara terusmenerus selama berada dilapangan, dari permulaan pengumpulan data, mulai mencari arti benda benda, mencatat keteraturan pola-pola (dalam catatan teori), penjelasan-penjelasan, konfigurasi- konfigurasi yang mungkin, alur sebab akibat dan proposal. Kesimpulankesimpulan itu kemudian diverifikasi kembali dengan mempertimbangkan dan meninjau kembali catatan lapangan sehingga terbentuk penegasan kesimpulan.

$$
\begin{aligned}
& \text { F. Waktu dan Tempat Penelitian } \\
& \text { Penelitian dilaksanakan di Kantor }
\end{aligned}
$$

Fakultas Ilmu Sosial Universitas Negeri Padang. Alasan penulis memilih Kantor Fakultas Ilmu Sosial Universitas Negeri Padang sebagai lokasi

Jurnal JIPS (Jurnal Ilmiah Pendidikan Scholastic) Vol. 5 No. 3 (2021) ISSN : 2579-5449

This work is licensed under a Creative Commons Attribution-NonCommercial 4.0 International License. 
penelitian dikarenakan keterbatasan kemampuan, waktu, dan biaya peneliti untuk mendapatkan data dan informasi dalam meneliti.

Maret 2021 pada jam 14.09 WIB yang menyatakan bahwa:

"kualitas kinerja Aparatur Sipil Negara (ASN) di Kantor Ilmu Sosial Universitas Negari Padang sudah baik, sesuai dengan tujuan yang diharapkan dan kami sebagai mahasiswa dapat terlayani sesuai dengan kebutuhan, walaupun terkadang mahasiswa yang banyak mengurus surat-surat kemahasiswaan memang agak sedikit terlambat prosesnya, mungkin terlalu sibuk atau ada kegiatan lainnya yang mendesak".

Dari beberapa hasil wawancara diatas dapat penulis simpulkan bahwa kualitas kinerja Aparatur Sipil Negara (ASN) maupun bukan ASN di Kantor Fakultas Ilmu Sosial Universitas Negeri Padang sudah berjalan dengan baik, sesuai aturan, dan mendekati kesempurnaan atau sudah sesuai dengan harapan, walaupun pada suatu waktu beberapa mahasiswa yang mengurus administrasi di kantor mengalami keterlambatan surat menyurat, dan ini bisa saja disebabkan oleh sibuknya pegawai kantor atau ada kegiatan lain yang lebih penting didahulukan. Sehingga mahasiswa yang tidak mengetahui hal tersebut menjadi terlambat dalam pengurusan administrasinya.

2. Quantity (kuantitas) adalah jumlah yang dihasilkan, misalnya jumlah rupiah, jumlah unit, jumlah siklus kegiatan yang diselesaikan.

Berdasarkan hasil wawancara peneliti dengan Bapak "AR" dan beberapa Kasubag pada hari Rabu tanggal 03 Maret 2021 pada jam 10.17 WIB menyatakan bahwa:

"Setiap pekerjaan yang diberikan kepada Aparatur Sipil Negara (ASN) di Kantor Fakultas Ilmu Sosial sudah memenuhi kuantitas yang diharapkan atau siklus pekerjaan yang diselesaikan sudah sesuai dengan yang diharapkan sehingga sampai sekarang belum ada keluhan dari pihak lain, ini semua berkat Aparatur Sipil Negara (pegawai)yang memiliki komitmen tinggi dan ingin memberikan hasil pekerjaan yang tepat waktu dan berprestasi sehingga akan meningkatkan kinerja dan waktu penyelesaian pekerjaan yang singkat".

Jurnal JIPS (Jurnal Ilmiah Pendidikan Scholastic) Vol. 5 No. 3 (2021) ISSN : 2579-5449

This work is licensed under a Creative Commons Attribution-NonCommercial 4.0 International License. 
Dari hasil wawancara dengan pegawai dan beberapa dosen lain pada hari Rabu tanggal 03 Maret 2021 pada jam 11.28 WIB yang menyatakan bahwa: "sejauh ini kualitas maupun kuantitas Aparatur Sipil Negara (pegawai)di Kantor Fakultas Ilmu Sosial sudah berjalan dengan prosedur yang ada, tepat waktu dan hasilnya sangat memuaskan sehingga kami para dosen tidak terlalu memikirkan administrasi lagi".Ditambahkan juga oleh beberapa mahasiswa yang menyatakan bahwa:

"Sejauh ini kami para mahasiswa sudah terlayani dengan baik, kecermatan dan ketepatan waktu dalam penyelesaian pekerjaan oleh ASN di Kantor Fakultas Ilmu Sosial sudah bagus dan siklus administrasinya memuaskan, sehingga kami merasa segan dan hormat terhadap siapapun di kantor tersebut baik itu ASN maupun bukan".

Dari beberapa hasil wawancara diatas dapat penulis simpulkan bahwa kuantitas dan siklus pekerjaan Aparatur Sipil Negara (ASN) di Kantor Fakultas Ilmu Sosial Universita Negeri Padang sangat baik, siklus pekerjaan administrasinya sangat cepat dan memberikan yang terbaik kepada konsumennya, sehingga sampai saat ini belum ada keluhan administrasi, sehingga prestasi kinerja dapat ditingkatkan dan lebih percaya diri dalam melakukan setiap kegiatan rutinitas lainnya. Hal ini bisa saja terjadi dengan komitmen tinggi para ASN serta rasa tanggungjawab dalam pekerjaan dan penyelesaian pekerjaan dengan cepat dan tepat pada waktunya, serta arahan pimpinan yang jelas dan mudah dipahami.

3. Timelines (waktu) adalah tingkat sejauh mana suatu kegiatan diselesaikan pada waktu yang dikehendaki, dengan memperhatikan koordinasi output lain serta waktu yang tersedia untuk kegiatan lain.

Berdasarkan hasil wawancara peneliti dengan Bapak "AR" dan beberapa Kasubag pada hari Rabu tanggal 03 Maret 2021 pada jam 10.17 WIB menyatakan bahwa:

"Dalam pengamatan kami sejauh ini output serta waktu yang telah ditentukan mengenai suatu pekerjaan atau kegiatan yang diberikan kepada Aparatur Sipil Negara (pegawai)di Kantor Fakultas Ilmu Sosial sangat memuaskan dan sesuai dengan batas waktu yang diberikan, serta mengikuti arahan pimpinan dan bahkan terkadang selesai sebelum batas waktu yang ditentukan, sehingga waktu luang yang tersedia untuk kegiatan lain dapat digunakan sebaik mungkin dan melakukan persiapan yang lebih baik lagi pada kegiatan lainnya. Contohnya pada penerimaan mahasiswa baru yang sangat membutuhkan persiapan disemua bidang, itu sangat membutuhkan ketepatan waktu yang telah ditentukan sehingga semua pendataan kemahasiswaan dapat dipertanggungjawabkan, ini sangat membutuhkan ketelitian waktu yang tersedia dan waktu luang untuk kegiatan lainnya".

Hal senada juga disampaikan oleh beberapa pegawai dan dosen pada hari Rabu tanggal 03 Maret 2021 pada jam 11.28 WIB yang menyatakan bahwa: "Setiap kegiatan yang akan dilakukan memang harus membutuhkan persiapan yang ditentukan, sehingga satu kegiatan dengan kegiatan lainnya dapat dijalankan dengan jelas dan sebaik mungkin dilakukan dalam batas waktu yang telah ditentukan sebelumnya, maka dari itu setiap pimpinan harus dapat membuat jadwal kegiatan tahunan yang jelas dan dikoordinasikan dengan staf lainnya agar dapat terlaksana dengan memperhatikan output atau hasil yang diharapkan".

Hal senada juga disampaikan oleh beberapa mahasiswa pada hari Jumat tanggal 05 Maret 2021 pada jam 14.09 WIB yang menyatakan bahwa "kami sebagai mahasiswa juga mengikuti batasan waktu suatu kegiatan yang telah ditentukan, sehingga kami jelas kegiatan-kegiatan apa selanjutnya yang akan dilakukan dan itu semua juga mendisiplinkan kami dalam masalah waktu".

Dari beberapa hasil wawancara diatas dapat penulis simpulkan bahwa setiap kegiatan yang ada selalu tuntas dalam waktu yang telah ditentukan sebelumnya dengan hasil yang memuaskan, batasan waktu yang telah ditentukan itu selalu berdasarkan arahan atasan supaya satu kegiatan tidak bersinggungan dengan kegiatan lainnya. Batasan-batasan waktu ini biasanya telah ditentukan dalam rencana kegiatan tahunan, sehingga setiap kegiatan jelas waktu pelaksanaannya dan akan nampak output atau hasilnya akan memuaskan atau tidak.

4. Cost- effectiveness (efektifitas biaya) adalah tingkat sejauh mana penggunaan

Jurnal JIPS (Jurnal Ilmiah Pendidikan Scholastic) Vol. 5 No. 3 (2021) ISSN : 2579-5449

This work is licensed under a Creative Commons Attribution-NonCommercial 4.0 International License. 
sumberdaya organisasi (manusia, keuangan, tekhnologi, material) yang dimaksimalkan untuk mencapai hasil tertinggi atau pengurangan kerugian dari setiap unit penggunaan sumber daya.

Berdasarkan hasil wawancara peneliti dengan Dekan berini sial "ST" dan beberapa pada hari Rabu tanggal 03 Maret 2021 pada jam 10.17 WIB menyatakan bahwa:

"Sejauh ini kita selalu memaksimalkan sumber daya organisasi, keuangan, teknologi, material dan sumber daya manusia yang ada sehingga tingkat kerugian dapat diminimalisir atau dikurangi, serta perawatan teknologi dilakukan secara berkala dan hasilnya dilaporkan ke atasan, serta kita sangat berharap staff di kantor dapat menguasai teknologi, terutama komputer dan internet".

Hal senada juga disampaikan oleh beberapa pegawai dan dosen pada hari Rabu tanggal 03 Maret 2021 pada jam 11.28 WIB yang menyatakan bahwa "penggunaan sumber daya organisasi, teknologi, material lain, dan sumber daya manusia sudah sangat baik, hanya saja staf di kantor harus paham perkembangan teknologi yang sangat pesat dan selaku Aparatur Sipil Negara (pegawai)harus mengikuti perkembangan tersebut".

Sedangkan hasil wawancara dengan beberapa mahasiswa pada hari Jumat tanggal 05 Maret 2021 pada jam 14.09 WIB yang menyatakan bahwa:

"Di kantor Fakultas Ilmu Sosial para Aparatur Sipil Negara (ASN) kami lihat sudah memanfaatkan sumber daya organisasi yang ada serta memanfaatkan teknologi, dan kami sebagai mahasiswapun terkadang memang agak lambat mengikuti perkembangan teknologi ini, karena keterbatasan ekonomi yang ada pada saat pandemi ini benar-benar sangat mempengaruhi kehidupan orang tua kami, jadi sangat banyak diantara kami mahasiswa yang belum memiliki komputer atau laptop, printer, dan jaringan internet sedangkan barang tersebut sangat kami butuhkan dalam perkuliahan online yang diadakan oleh kampus".

Dari beberapa hasil wawancara di atas dapat penulis simpulkan bahwa penggunaan sumberdaya organisasi (manusia, keuangan, tekhnologi, material) yang dimaksimalkan untuk mencapai hasil tertinggi atau pengurangan kerugian dari setiap unit penggunaan sumber daya sudah dapat terlaksana dengan baik terutama di Kantor Fakultas Ilmu Sosial, Aparatur Sipil Negara (ASN) sudah menguasai teknologi dan memahami pemanfaatan teknologi pada setiap bidang pekerjaan yang ada.

Namun perkembangan teknologi tersebut pada saat pandemi covid 19 sangat berdampak bagi mahasiswa yang belum memiliki komputer, laptop, printer dan jaringan internet. Pandemi covid 19 ini sangat mempengaruhi ekonomi pada saat ini sehingga para orang tua sangat banyak yang kehilangan pekerjaannya dan tentu belum mampu mencukupi anaknya yang sedang kuliah online. Sehingga para mahasiswa terpaksa meminjam barang-barang tersebut ke teman atau tetangga lain yang ada.

Adapun bantuan pulsa dari Kemdikbud $50 \mathrm{~Gb}$ per mahasiswa tidak mencukupi kebutuhan yang ada, bahkan terkadang di kampung mahasiswa tidak terdapat jaringan internet sehingga mahasiswa harus mencari jauh ke daerah lain untuk mendapatkan jaringan internet. Hal ini tentu sangat mempersulit mahasiswa dalam pembelajaran online pada saat pandemi covid 19 ini.

5. Need for supervision (perlu pengawasan) adalah tingkat sejauhmana seseorang pekerja dapat melaksanakan suatu fungsi pekerjaan tanpa memerlukan pengawasan seorang supervisor untuk mencegah tindakan yang kurang diinginkan.

Berdasarkan hasil wawancara peneliti dengan Bapak "AR" dan beberapa Kasubag pada hari Rabu tanggal 03 Maret 2021 pada jam 10.17 WIB menyatakan bahwa:

"Aparatur Sipil Negara (ASN) di Fakultas Ilmu Sosial sudah memahami tugastugas pekerjaan yang diberikan dan sudah sesuai dengan aturan dan arahan pimpinan, namun beberapa sektor memang terkadang harus diawasi seperti bendahara, pengurus barang dan kemahasiswaan jangan sampai salah menginput data dan sangat butuh ketelitiannya, karena jika kurang hati-hati bisa saja akan menyebabkan kerugian bagi universitas maupun mahasiswa".

Hal senada juga disampaikan oleh beberapa pegawai dan dosen pada pada hari Rabu tanggal 03 Maret 2021 pada jam 11.28 WIB yang menyatakan bahwa "selama ini kami lihat pekerjaan Aparatur Sipil Negara (pegawai)dan staf lain sudah bagus dan tidak perlu diawasi lagi, sudah memahami pekerjaan

Jurnal JIPS (Jurnal Ilmiah Pendidikan Scholastic) Vol. 5 No. 3 (2021) ISSN : 2579-5449

This work is licensed under a Creative Commons Attribution-NonCommercial 4.0 International License. 
masing-masing dan mengikuti aturan yang berlaku, sehingga kami para dosen tidak ada kendala di kantor jadi kami percayakan saja administrasi di kantor".

Ditambahkan juga oleh beberapa mahasiswa pada hari Jumat tanggal 05 Maret 2021 pada jam 14.09 WIB yang menyatakan bahwa "Staf di Kantor Fakultas Ilmu Sosial sudah memahami pekerjaan masing-masing dan sejauh ini selalu tahu saja apa yang kami butuhkan selaku mahasiswa dan tidak ada kendala yang berarti selama ini".

Dari beberapa hasil wawancara di atas dapat penulis simpulkan bahwa staf di Kantor Fakultas Ilmu Sosial Universitas Negeri Padang sudah memahami fungsi dan tugas pokok pekerjaan masing-masing, sehingga tidak selalu memerlukan pengawasan, namun beberapa sektor seperti bendahara, pengurus barang dan kemahasiswaan memang diperlukan pengawasan yang ahli di bidangnya, karena bendahara dan pengurus barang itu sangat membutuhkan ketelitian dan ketepatan dalam pekerjaannya, sehingga didapatkan hasil pekerjaan yang maksimal dan dapat mencegah kesalahan di masa yang akan datang.

6. Interpersonal impact (dampak interpersonal) adalah tingkat sejauh mana karyawan memelihara harga diri, nama baik dan kerja sama diantara rekan kerja dan bawahan.

Berdasarkan hasil wawancara peneliti dengan Bapak "AR" dan beberapa Kasubag pada hari Rabu tanggal 03 Maret 2021 pada jam 10.17 WIB menyatakan bahwa "kami selalu memelihara harga diri, nama baik dan kerjasama diantara rekan kerja dan bawahan, kami seperti keluarga besar yang melakukan tugas pokok dan pekerjaannya masing-masing, jadi kami saling menghargai satu sama lainnya dalam suka maupun duka".

Hal senada juga disampaikan oleh beberapa pegawai dan dosen di Kantor Fakultas Ilmu Sosial pada hari Rabu tanggal 03 Maret 2021 pada jam 11.28 WIB yang menyatakan bahwa "staf di Kantor selalu menjaga nama baik dan saling bekerjasama diantara rekan kerja atasan maupun bawahan dalam penyelesaian pekerjaan, namun terkadang memang agak terjadi kecemburuan sosial dalam hal jabatan diantara staf di kantor".

Ditambahkan juga oleh beberapa mahasiswa pada Jumat tanggal 05 Maret 2021 pada jam 14.09 WIB yang menyatakan bahwa "staf di kantor fakultas selalu kompak dan bekerjasama dengan baik dalam penyelesaian setiap pekerjaan, kami sebagai mahasiswa juga mengapresiasi hal tersebut dan semoga terus dapat dipertahankan".

Dari beberapa hasil wawancara di atas dapat penulis simpulkan bahwa staf di Kantor Fakultas Ilmu Sosial dapat memelihara harga diri, nama baik dan kerja sama diantara rekan kerja dan bawahan pada umumnya, walaupun sebenarnya diantara sesama karyawan selalu ada kecemburuan dalam hal jabatan yang didapatkan, terkadang seseorang yang merasa pantas menduduki suatu jabatan namun tidak ada dukungan atasan akan menyebabkan kecemburuan jabatan dan hal ini akan menjadi kurang maksimalnya hasil pekerjaan yang didapatkan.

\section{CONCLUSION}

Setelah penulis melaksanakan penelitian di Fakultas Ilmu Sosial Universitas Negeri Padang dan menganalisa data yang didapatkan di lapangan, maka dapat diambil beberapa kesimpulan, yaitu sebagai berikut:

1. Kinerja Aparatur Sipil Negara (ASN) di Kantor Fakultas Ilmu Sosial Universitas Negeri Padang.

Kinerja Aparatur Sipil Negara (ASN) di Kantor Fakultas Ilmu Sosial Universitas Negeri Padang secara umum sudah berjalan dengan baik dan sesuai arahan dan aturan yang berlaku, untuk peningkatan kinerja ASN diperlukan arahan dan kesadaran ASN itu sendiri sehingga dapat lebih meningkatkan kinerja di Kantor Fakultas Ilmu Sosial Universitas Negeri Padang.

2. Kendala-kendala dalam Kinerja Aparatur Sipil Negara (ASN) di Kantor Fakultas Ilmu Sosial Universitas Negeri Padang.

Pada masa pandemi covid 19 ini memang sangat menyulitkan berbagai sektor, terutama sektor pendidikan dan ekonomi yang berdampak langsung dengan orang tua dan bagi mahasiswa itu sendiri sehingga akan 
mempengaruhi kinerja Aparatur Sipil Negara (ASN) di Kantor Fakultas Ilmu Sosial Universitas Negeri Padang.

3. Cara Mengatasi kendala yang ditemui dalam Kinerja Aparatur Sipil Negara (ASN) di Kantor Fakultas Ilmu Sosial Universitas Negeri Padang.

Cara mengatasi kendala yang ditemui dalam Kinerja Aparatur Sipil Negara (ASN) dengan selalu mensosialisasikan setiap ada sistem baru yang digunakan pihak kampus, sehingga dalam prosesnya semua pihak dapat memahaminya, serta pada masa pandemi covid 19 ini sangat diperlukan perhatian dari pihak kampus terhadap mahasiswa yang terdampak dan ketiadaan fasilitas untuk pembelajaran jarak jauh yang sudah diterapkan.

\section{B. Saran}

Setelah pembahasan skripsi ini, supaya pembahasan dan pikiran-pikiran yang tertuang dalam skripsi ini dapat bermanfaat bagi berbagai pihak, maka penulis menyampaikan beberapa saran sebagai berikut:

1. Saran untuk Fakultas

Pihak Fakultas menyediakan labor komputer untuk mahasiswa yang kesulitan dalam pembelajaran jarak jauh, sehingga pembelajaran tetap berjalan dan tugas-tugas kampus tetap dilaksanakan dengan baik oleh mahasiswa.

2. Saran untuk pemerintah

Perhatian pemerintah sangat dibutuhkan oleh mahasiswa, bantuan berupa paket internet untuk mahasiswa ternyata belum mampu memenuhi kebutuhan mahasiswa, terutama yang berada di daerah-daerah terisolir yang memang sulit dijangkau jaringan internet.
3. Saran untuk Kabag Tata Usaha

Sebagai pimpinan di kantor administrasi sebaiknya selalu memperhatikan dan memberikan arahan yang baik serta menjadi contoh teladan bagi bawahan supaya administrasi lebih tertata lebih baik lagi dan mempermudah urusan dengan kemahasiswaan maupun dosen lain.

4. Saran untuk mahasiswa

Mahasiswa yang ingin berurusan dengan administrasi di kantor fakultas seharusnya dapat memahami proses eletter yang masih tergolong baru diterapkan, serta bagi mahasiswa yang kesulitan dalam pembelajaran jarak jauh diharapkan berkonsultasi dengan dosen yang bersangkutan untuk mencari solusi yang lebih baik lagi.

5. Saran untuk peneliti

Adapun beberapa saran yang perlu diperhatikan bagi peneliti selanjutnya yang tertarik tentang Kinerja Aparatur Sipil Negara (ASN) di Kantor Fakultas Ilmu Sosial Univesitas Negeri Padang, sebagai berikut:

a. Peneliti selanjutnya diharapkan untuk mengkaji lebih banyak sumber maupun referensi yang terkait dengan kinerja Aparatur Sipil Negara (ASN) agar hasil penelitiannya dapat lebih lengkap lagi.

b. Peneliti selanjutnya diharapkan lebih mempersiapkan diri dan segala sesuatunya dalam proses pengambilan dan pengumpulan data sehingga penelitian dapat dilaksanakan dengan lebih baik lagi. Peneliti selanjutnya diharapkan ditunjang pula dengan wawancara dengan sumber yang kompeten dalam kajian Kinerja Aparatur Sipil Negara (ASN) berdasarkan aturan yang berlaku. 


\section{Bibliography}

[1]Ahmad Tafsir, 2007. Metodologi Pengajaran Agama Islam, Bandung: PT Remaja Rosdakarya.

[2]Arikunto, S. 2006, Metode Penelitian Kualitataif, Jakarta: Bumi Aksara.

[3]As'ad, Mohammad. 1995.Psikologi Industry. Edisi Keempat, Yogyakarta : Liberty.

[4]Dwiyanto, Agus. 2006.Reformasi Birokrasi Publik di Indonesia. Yogyakarta : UGM Press.

[5]Hasan, M. Iqbal. 2002, Pokok-Pokok Materi Metodologi Penelitian dan Aplikasi.

[6]Inu Kencana. 2006. Ilmu Administrasi Publik. Jakarta: PT.Rineka Cipta.

[7]Mahmudi. 2005. Manajemen Kinerja Sektor Publik. Yogyakarta : UPP AMP YKPN. M. Mahsun. 2006. Pengukuran Kinerja Sektor Publik.. Yogyakarta,: BPFE.

[8]Malayu, S.P Hasibuan. 1999. Manajemen Dasar, Pengertian dan Masalah, Buku I. Jakarta : CV. Haji Masagung.

[9]Marshall, Catherine \& Gretchen, B. Rossman. 1995, Desinging Qualitative

[10]Moleong, L. J. 2010, Metodologi Penelitian Kualitataif, Bandung: Remaja Rosda Karya.

[11]Miles, M.B \& Huberman, A.M. 1992, Qualitative Data Analysis, Beverly Hills:

[12]Modul Pendidikan dan Pelatihan Pelayanan Prima Bukan Diklat. Jakarta:Posdiklat

[13]Nasution. 1988, Metode Research (Penelitian Ilmiah). Jakarta: Bumi Aksara.
[14]Sedarmayanti,.2007. Manajemen Sumber Daya Manusia.Bandung : PT. Refika Aditama.

--2003. Good Governance:

Dalam Rangka Otonomi Daerah Upaya Membangun Organisasi Efektif dan Efisien melalui Restrukturasi dan Pemberdayaan, Ed 1,Bandung : Mandar Maju.

---------. 2010. Manajemen Sumber Daya Manusia Birorasi dan Manajemen Pegawai Negeri Sipil. Bandung : PT Refika Aditama.

[15]Sendow. 2007.Pengukuran Kinerja Karyawan. Jakarta : Gunung Agung.

[16]Simamora, Henry 1995. Manajemen Sumber Daya Manusia, STIE YKPN, Jakarta: Bumi Aksara.

[17]Silalahi, Ulber. 2010, Metode Penelitian Sosial, Jakarta: Refika Aditama.

[18]Spradley, J.P. 1988, Metode Penelitian, Yogyakarta: Tiara Wacana.

[19]Stephen P ,Robbins, 1996. Perilaku Organisasi, Edisi Bahasa Indonesia, Jakarta : Prinhalindo.

[20]Sugiyono, 2005. Metode Penetian Administrasi, Alfabeta: Bandung. ---------.2016. Metode Penelitian Kuantitatif, Kualitatif dan $R \& D$. Bandung:Alfabeta

[21]Undang- Undang Nomor 43 Tahun 1999 tentang Pokok-Pokok Kepegawaian

[22]Undang- Undang nomor 5 tahun 2014 tentang Aparatur Sipil Negara (ASN)

Jurnal JIPS (Jurnal Ilmiah Pendidikan Scholastic) Vol. 5 No. 3 (2021) ISSN : 2579-5449

This work is licensed under a Creative Commons Attribution-NonCommercial 4.0 International License. 